\title{
1 The effects of altered flow and bed sediment on macroinvertebrates in stream mesocosms.
}

2 Ivor Growns ${ }^{1}$, John F. Murphy ${ }^{2}$ and J. Iwan Jones ${ }^{2}$

31 - Environmental and Rural Sciences, University of New England, Armidale, NSW, Australia 2351.

42 - School of Biological and Chemical Sciences, Queen Mary University of London, London, E1

$5 \quad 4 \mathrm{NS}, \mathrm{UK}$

\section{Abstract}

7 River regulation and altered land use are common anthropogenic disturbances resulting in ecological

8 impacts through siltation or altered hydrology. We tested the separate and combined effects of

9 increased flow and fine particles (colmation) on macroinvertebrates in flume mesocosms. We hypothesised that increased flow would reduce any effects of colmation. We tested two bed types: clean and colmated sediment where fines were $10 \%$ by weight. Two flow rates were initially established, a turbulent flow in six mesocosms and a lower rate to create a transitional flow between turbulent and laminar flows in the remaining six mesocosms. After 30 days macroinvertebrates were sampled and the flow in three turbulent flow mesocosms and three transitional flow mesocosms switched to the lower and higher flow rates, respectively, thus creating four flow scenarios. The experiment was concluded after sampling macroinvertebrates again at day 70 . We demonstrated that colmation and decreased flows individually result in decreased density and richness of macroinvertebrates and altered assemblage and trait structure. However, our hypothesis that higher flows would ameliorate any effects of fines was not supported. Further research is required to evaluate if lower thresholds of colmation have ecological impacts and determine the velocities required to ameliorate those impacts. 
Modification of flows in regulated rivers is arguably the greatest source of human alteration of riverine ecosystems, with nearly $80 \%$ of the discharge of rivers being affected (Nilsson et al. 2005; Carlisle et al. 2010). There are four ways in which flow modification is likely to cause ecological effects (Ward and Stanford 1979). First, rivers with reduced flow will have decreased local current velocities, decreased overall stream habitat and increased siltation of the stream bed. Second, streams with constant seasonal flows will have uniform currents, which may enhance riparian and aquatic vegetation through bed stability. Third, increased discharge may lead to higher current velocities leading to bed scour, resulting in a change to a coarse substratum. Fourth, short-term fluctuations in flow created during the generation of hydro-electricity can cause current and depth fluctuations, turbidity and bed and bank instability. There are two main physical impacts from river regulation: alteration of flow and, as a consequence, changed sediment dynamics (Buendia et al. 2014).

The flow of water in a river determines many critical physicochemical characteristics such as channel geomorphology, sediment dynamics and habitat diversity, and limits the distribution and abundance of riverine species (Biggs et al. 2005; Larned et al. 2010). Alteration of the natural flow regime alters many of the naturally occurring ecological and physical processes and properties (e.g. Menéndez et al. 2012; Araujo et al. 2013; Ruiz-Gonzalez et al. 2013; Growns et al. 2014). Specifically, changes in flow regimes and near-bed hydraulics can modify sediment retention (Palmer et al. 2014), macroinvertebrate assemblage and trait structure (Brooks et al. 2005; Brooks et al. 2011), periphyton assemblages (Hart et al. 2013), benthic metabolism (Reid et al. 2006), carbon uptake by algae (Finlay and Sinsabaugh, 1999), insect larval sizes (Sagnes et al. 2008) and feeding efficiency rates in filter-feeding invertebrates (Lancaster and Downes 2010). It is not surprising then that river regulation leads to ecological change and that the risk of ecological change increases with increasing magnitude of flow alteration (Bunn and Arthington 2002; Poff and Zimmerman 2010; Cortez et al. 2012). 
surface water from the hyporheic zone (Brunke 1999). Colmation can occur either under low flows where the settling of particles can cause external colmation or following flooding which can cause silt to deposit within the stream bed (Olsen et al. 2010). Increased amounts of fine-grained sediment in the river bed can affect benthic macroinvertebrate assemblage structure and trait characteristics through clogging of gills and other body parts (Kefford et al. 2010; Descloux et al. 2014), mortality through burial (Wood et al. 2005), removal of habitat through filling of interstitial spaces (Vadher et al. 2015) and decreased bed stability (Kaufmann et al. 2009). The relationship between macroinvertebrates and fine-grained sediments is poorly defined (Jones et al. 2012), however, negative ecological responses can occur with small additions of surface sediment (Bryce et al 2010; Wagenhoff et al. 2012)

The relationship between flow and colmation of substrata is not straightforward. Whilst peak flows can be associated with the delivery of large quantities of fine-grained sediment from the catchment, in areas of the river bed experiencing high flow, frequently occurring flood events tend to clear fine-grained sediments allowing an exchange of oxygen-rich surface water with the pore water of hyporheic interstices (Gibson, 2002; Mürle et al. 2003). In simple terms, the behaviour of finegrained sediment within rivers is influenced by hydrologic conditions, whereas the load of finegrained sediments entering rivers is largely dependent on landscape erosion within the catchment (Boulton et al. 1997; Collins and Anthony 2008), with both factors interacting to govern the rate of colmation. As drivers such as forestry and agricultural intensification tend to be associated with changes to both flow and fine-grained sediment load (i.e. hydromorphological changes to increase drainage and increased tillage) there is considerable advantage to understanding the separate and combined influence of sediment and flow on benthic conditions. To date, experimental investigations of the combined effects of colmation and altered flow on benthic macroinvertebrates are rare.

Here we present an experimental investigation where we artificially manipulated the amount of fine-grained sediment in the stream bed and flow rates in the channel and examined their individual and joint effects on benthic macroinvertebrate assemblages. We hypothesised that, in addition to individual treatment effects, there would be a strong interaction effect of stream flow and colmation, 
specifically that high flow rates would reduce the ecological effects of colmation through increased inter-gravel flows and potentially flushing of fine-grained sediments from the stream bed. Further, we tested the hypothesis that low flows would have a lasting effect on invertebrate assemblages even after flows had been increased. Such legacy effects of changes in hydrology have been noted before (Ledger et al. 2006; Ledger and Hildrew 2001), and are a consequence prior effects on the species present. Our objective here was to establish if the invertebrate assemblage was resilient to changes in hydrology, and thus to establish the implications of periods of low flow.

\section{Methods}

Study area

The River Frome has a catchment area of $414 \mathrm{~km}^{2}$, which is underlain mainly by Cretaceous Chalk bedrock. The land use is primarily agricultural and Dorchester is the only significant urban area in the catchment, with a population of 19,000 in 2013 (Office of National Statistics, 2014). For the period 1965 to 2005, the mean annual rainfall at East Stoke was $1020 \mathrm{~mm}$ and the mean annual discharge was $6.38 \mathrm{~m}^{3} \mathrm{~s}^{-1}$ (Marsh and Hannaford 2008).

\section{Experimental design}

The experiment was carried out between May and August 2012 in twelve open-air, flow-through flume mesocosms located at the Freshwater Biological Association's River Laboratory $\left(50^{\circ} 40^{\prime} 49^{\prime} \mathrm{N}\right.$, $2^{\circ} 11^{\prime} 05^{\prime}$ W) in Dorset, U.K. Four blocks of mesocosms were sited adjacent to, and fed from, the Mill Stream, a side channel of the River Frome. Each block consisted of three parallel linear steel flumes ( $0.33 \mathrm{~m}$ width, $12.4 \mathrm{~m}$ length and $0.30 \mathrm{~cm}$ depth) positioned at approximately $140^{\circ}$ to the riverbank.

Mesocosms were filled to a depth of $20 \mathrm{~cm}$ with sediment sourced from a local quarry to replicate the sediment-size distribution of the Mill Stream (volumetric proportions of particle sizes, 85\% 11-25 mm, 5\% 2-11 mm, 5\% 0.35-2 mm, 5\% 0-0.35 mm (Armitage, 1995; Ledger et al. 2008).

Sediments were mechanically mixed to ensure homogeneity prior to use. To mimic internal colmation, fine-grained river sediment $(<2 \mathrm{~mm}$ size fraction, obtained from dredged river bed material) was added to the sediment placed in the downstream $4 \mathrm{~m}$ stretch of each mesocosm. In these 
sections total fine-grained sediment represented $10 \%$ of the total sediment by weight. We chose $10 \%$ as ecological impairment potentially occurs when fine sediment reaches this level (see Kemp et al. 2011). Therefore, each mesocosm contained two bed sediment types: "clean" sediment in the upstream most $4 \mathrm{~m}$ section and experimentally colmated sediment in the downstream most $4 \mathrm{~m}$ section. The intervening $4 \mathrm{~m}$ was treated in the same way (upstream $2 \mathrm{~m}$ filled with clean sediment, downstream $2 \mathrm{~m}$ filled with experimentally colmated sediment) but treated as a buffer region between the sediment treatments (i.e. not sampled), in case there was migration of fine-grained sediment between treatments. Three replicate five litre sediment samples were taken randomly from the clean and experimentally colmated bed sediments. These samples of bed sediment were dried and sieved into $<0.125,0.25,0.5,1.0,2.0,4.0,8.0$ and $16 \mathrm{~mm}$ or greater size fractions and the dry mass of each determined. For each size fraction the percentage organic matter was calculated from loss on ignition following combustion at $450^{\circ} \mathrm{C}$ in a muffle furnace.

Unfiltered river water was delivered at the head of each block through an upstream inflow pipe (110 mm diameter) into a reservoir, approximately $2 \mathrm{~m}$ long, $1 \mathrm{~m}$ wide and $35 \mathrm{~cm}$ deep. From this reservoir, water flowed by gravity over a low weir into the upper end of each channel, creating a localised affect in the first $100 \mathrm{~mm}$ of the upstream section in each mesocosm; flow rates in the individual mesocosms were controlled by adjusting the height of the weir. Macroinvertebrates colonised the mesocosms by drift from the Mill Stream or aerially (Harris, 2006).

Two flow rates were initially established in the twelve mesocosms. The higher flow rate (mean $5.3 \times 10^{-3} \mathrm{~m}^{3} \mathrm{~s}^{-1}$ range $4.7 \times 10^{-3}$ to $6.1 \times 10^{-3}$ ) was chosen to create turbulent flow (Reynolds number $>2000)$ and the lower flow rate $\left(3.2 \times 10^{-4} \mathrm{~m}^{3} \mathrm{~s}^{-1}\right.$ range $2.7 \times 10^{-3}$ to $\left.3.9 \times 10^{-3}\right)$ was chosen to create a transitional flow between turbulent and laminar flows (Reynolds number between 500 and 2000). The higher and lower flow rates were assigned to each mesocosm alternately along the eastwest direction. Flow was started in each mesocosm in May 2012. After 40 days, flow rates in six out of twelve of the mesocosms were switched; three of the higher flow flumes were altered to the low flow rate and three of the slower flow mesocosms were increased to the high flow rate. Therefore, we had four flow scenarios: fast flow throughout the experiment (FF flow scenario), slow flow 
throughout (SS), fast flow for 40 days and then changed to slow flow (FS) and slow flow for 40 days changed to fast flow (SF). The experiment was concluded at day 70 .

\section{Macroinvertebrate and physico-chemical sampling}

Electrical conductivity, $\mathrm{pH}$ and temperature were measured with a regularly calibrated hand-

held electronic meter (Hanna Instruments HI98129) in each of the experimental sections at the start of the experiment, at four day intervals until the end of day 40 when the flows in some channels were changed, then at 8 day intervals and at the termination of the experiment on day 70 .

Macroinvertebrates were sampled using 25 x $25 \mathrm{~cm}$ Surber sampler ( $300 \mu \mathrm{m}$ mesh), with the substrate disturbed to a depth of approximately $3 \mathrm{~cm}$, at day 30 and day 70 . Six randomly placed samples were taken from of each $4 \mathrm{~m}$ sediment-type section in each mesocosm. Samples were preserved with $4 \%$ formaldehyde for subsequent identification and quantification to family level, with the exceptions that chironomid larvae were identified to subfamily and mites, nematodes and ostracods to order.

\section{Macroinvertebrate traits}

Data describing freshwater macroinvertebrate traits were obtained from Tachet et al. (2000) with additional information from www.freshwaterecology.info and Descloux et al. (2014) for those taxa or traits that were not included in Tachet et al. (2000). Each biological trait, e.g. mode of respiration, was described by several trait-classes, e.g. respiring via tegument, gill, spiracle or plastron. The trait characteristics of each taxon were scored by assigning a value to each trait-class reflecting the affinity of the taxon to the trait-class (Table 2). Scores ranged from 0 to 5 , indicating no to high affinity, respectively (Chevenet et al. 1994). Fuzzy coding was used where taxa were not exclusive to a single trait-class. The trait assemblage data was presented as a matrix of the relative prevalence of each trait-class (within each trait) in each of the 24 experimental sections on both sampling occasions. This matrix was created by first log-transforming the mean abundance of each recorded taxon from the six Surber samples taken in each experimental section on each sampling occasion. The trait-class scores for each recorded taxon were then multiplied by its log-transformed mean abundance to provide weighted trait-class scores. These were summed across recorded taxa 
within a trait class and then expressed as a proportion of the total sum of weighted trait-class scores within a trait to give the relative prevalence of each trait-class (within each trait) in each of the 24 experimental sections on both sampling occasions.

\section{Statistical analyses}

Differences in water quality, macroinvertebrate richness, density, community assemblage structure and trait assemblage structure between the fixed factors sampling occasion, flow scenario and bed sediment type were tested using Permutational Analysis of Variance (PERMANOVA) (Anderson 2001). The main factors sediment type and flow scenario were used as tests of the independent effects of sediment and flow, and their interaction to test for any ameliorative effect of increased flow on the effect of experimental colmation. The interaction between flow scenario and sampling occasion was also of interest, to test the effects of reversing flow on day 30 in the FS and SF flow scenarios (see Table 1). The random factor mesocosm was nested in the sediment type and flow scenario. Given there were twelve mesocosms, there were three replicates of each combination of the main factors. Individual samples, six taken from each experimental section on each sampling occasion, were pooled to give a single sample for each replicate channel.

To address our hypotheses we used planned contrasts to compare physicochemical variables and the macroinvertebrate assemblage among flow scenarios. To test for the immediate effects of flow, the fast-flow scenarios were compared with the slow-flow scenarios in place at the time of the first sampling occasion (FF and FS with SS and SF) and second sampling occasion (FF and SF with SS and FS). To test for legacy effects of historical flow, planned contrasts were used to compare within the fast-flow and slow-flow scenarios on both sampling occasions, i.e. FF with FS and SS with SF on the first sampling occasion and, FF with SF and SS with FS on the second sampling occasion. Planned contrasts allowed us to examine pairs of flow scenarios in specific comparisons rather examining all possible post-hoc pairwise comparisons. Planned contrasts were only conducted when the flow scenario main factor was significant in the main model. 

log-transformed to minimise skewed distributions. Euclidean distance was used to form similarity matrices as input for the PERMANOVA analysis for water chemistry, and macroinvertebrate density, richness and trait assemblage structure. Bray-Curtis distance was used to form similarity matrices for the macroinvertebrate community assemblage data following range standardisation by dividing each taxon by its maximum density to ensure equal weighting of each taxon in the dissimilarity value. Significant relationships among the main factors and interactions were tested using a Monte Carlo procedure with 9999 randomisations. Patterns of differences in macroinvertebrate community and trait assemblages identified by PERMANOVA were presented diagrammatically using non-metric multidimensional scaling ordination (nMDS). The algorithm similarity percentages (SIMPER) was used to identify macroinvertebrate taxa or traits contributing to differences in main factors identified by PERMANOVA.

\section{Results}

The experimental manipulation of the sediment in the mesocosm produced a significant difference in substrate particle size (as percentage by weight) between the experimental sediment treatments (pseudo- $F=314 ; \mathrm{df}=8,1 ; P=0.0001$ : Figure 1). The mean percentage (all means \pm 1 standard error) of particles smaller than $2 \mathrm{~mm}$ was greater $(9.8 \pm 1.0 \% \mathrm{w} / \mathrm{w})$ in experimentally colmated sediment than the clean sediment $(6.2 \pm 0.6 \% \mathrm{w} / \mathrm{w})$. The mean organic content of the experimentally colmated sediment was also greater $(4.8 \pm 0.4 \% \mathrm{w} / \mathrm{w})$ when compared with the clean sediment $(0.0 \pm 0.0 \%$ $\mathrm{w} / \mathrm{w})$. mesocosms (Table 1), most likely a consequence of temporal changes in the source of the water, the River Frome. A slight but statistically significant difference in temperature and $\mathrm{pH}$ was found between the sediment treatments. Mean temperature in the experimental colmated substrate sections 

was also slightly greater in the experimental colmated substrate sections $(8.6 \pm 0.04)$ compared with the clean sediment sections $(8.5 \pm 0.03)$. There was no significant difference in water quality between the different flow scenarios.

\section{Response of macroinvertebrates - immediate effects and their interactions}

Macroinvertebrate richness, density and community and trait assemblage structure were all significantly influenced by the sediment experimental treatment (Table 1). Richness, community and trait assemblage structure were also influenced by sampling occasion and flow scenario (Table 1).

One of the terms of interest, the sediment by flow scenario interaction was not significant for any of the four biological measures, suggesting that flow regimes did not greatly influence the effects of the added fine-grained sediment on macroinvertebrate richness, density, community or trait assemblage structure (Table 1). In addition, the sediment by sampling occasion interaction was not significant for any of the biological measures, suggesting that any effects of the fine-grained sediment addition were constant through time (Table 1).

Overall, the mean richness was $26.4 \pm 1.0$ taxa in clean sediment compared with $23 \pm 0.7$ taxa in experimentally colmated sediment, and the mean number of taxa increased from $23 \pm 1.0$ at day 30 to $26 \pm 0.8$ at day 70 (Figure 2). Clean sediment in the FF flow scenario had a significantly greater number of taxa than the experimentally colmated sediments, but this did not occur for the other flow scenarios. Macroinvertebrate richness was significantly greater when the flow was fast, i.e. in flow scenarios FF and FS on day 30 and SF and FF on day 70 (Table 1). The increased richness in the SF flow scenario from day 30 to day 70 and decrease in the FS flow scenario from day 30 to day 70 (Figure 2), probably explain the significant interaction between flow scenario and sampling occasion. 
day 70. While, in experimentally colmated sediments mean density remained the same, varying from $2293 \pm 198$ to $2320 \pm 49$ animals per $\mathrm{m}^{2}$ over the same time.

There was a significant interaction between flow scenario and sampling occasion for both macroinvertebrate community and trait assemblage structure, indicating that the influence of flow regime changed through time. For both assemblage measures, on day 30 the two fast flow scenarios (FF and FS) were not significantly different to each other but were significantly different to assemblages from the slow flow scenarios (SS and SF: Table 1). These results are illustrated in the nMDS ordination plots where for both community and trait assemblages a similar pattern is evident (Figure 3). The fast flow scenarios (FF and FS) and slow flow scenarios (SS and SF), respectively, occupy similar positions in the ordination space on day 30 , indicating that they support similar assemblages (Figure 3). In contrast, on day 70, while the fast (FF and SF) scenarios were significantly different to each other, they were more distinctly different to the slow (SS and FS) flow scenarios, explaining the interactions between sampling occasion and flow scenario (Table 1). These results confirm that the macroinvertebrate community and trait assemblages responded to flow within the mesocosms; switching the flow from fast to slow or from slow to fast at day 40 resulted in the faunal assemblage changing to become more similar to the slow controls (SS) or fast controls (FF), respectively, at day 70 (Figure 3).

Four macroinvertebrate taxa contributed up to $20 \%$ of the significant differences between fast and slow flow scenarios on day 30 (Table S2). Athericidae, Baetidae and Ephemerellidae were more abundant in the faster flowing mesocosms and Dytiscidae more abundant in the slower flow scenarios. Five taxa including, Hydropsychidae, Baetidae, Hydroptilidae, Polycentropodidae and Leuctridae, contributed up to $20 \%$ to the significant differences between the fast and slow flow scenarios on day 70. With the exception of Leuctridae, all these taxa were more abundant in the faster flow scenarios. Seven taxa contributed up to $20 \%$ of the difference in macroinvertebrate assemblages between sediment types (Table S3). Leuctridae, Ephemeridae and Baetidae were more abundant in the 
experimentally colmated sediment type, whilst Dytiscidae, Hirudinea, Hydracarina and Caenidae were more abundant in the clean sediments.

The prevalence of three traits: potential number of life cycles per year, maximal potential size, and reproduction were significantly affected by the experimental treatments (Tables S2 and S3). The prevalence of animals with more than one life cycle per year was greater in slow flowing experimental areas and in colmated sediments (Figure 3). The prevalence of macroinvertebrates with a maximum potential size of $0.5-1 \mathrm{~cm}$ was also greater in colmated than clean sediment but in fast rather than slow flowing experimental areas. The prevalence of laying fixed clutches of eggs was less in colmated than clean sediments and greater in slow flows after 70 days. . After 30 days the prevalence of laying unattached clutches of eggs was greater in slow flow treatments than fast flow treatments (Tables S.2 and S3; Figure 3).

Response of macroinvertebrates - legacy effects

At the end of the experiment the planned contrasts identified differences in macroinvertebrate community structure between the two slow flow (SS v FS) treatments and between the two fast flow (FF v SF) treatments (Table 1: Figure 3a), indicating that prior flow conditions had a lasting influence on the invertebrate community. The effect size (pseudo- $F$ ) was larger for the difference between slow flow (SS v FS) treatments than between the fast flow (FF v SF) treatments (Table 1), suggesting that the flow switching had a more pronounced effect on prior fast flow than prior slow flow. The positions of the centroids in the nMDS ordination plot indicate that FS treatment was more distinct (further from the origin) than the SS treatment (Figure 3a), suggesting increased sensitivity to flow reduction in the prior fast flow community. The planned contrasts also identified an effect of previous flows on the trait assemblage, but here the effect size suggested the opposite pattern to the community response, with the difference between the fast flow (FF v SF) treatments returning a larger pseudo- $F$ than the slow flow (SS v FS) treatments (Table 1). In contrast to community composition (Figure 3a), the position of centroids suggest that prior flow conditions did not have a substantial differential effect on trait composition (Figure 3b). 
287

We have demonstrated that colmation and decreased flows individually result in decreased density and richness of macroinvertebrates and altered assemblage structure. However, our hypothesis that higher flows would ameliorate any effects of added fine sediment was not supported; there was no interaction between flow type and sediment treatment. These results are in contrast with the observation that increased flow can reduce the effects of sedimentation on macroinvertebrates (Matthaei et al. 2010). It is possible that the differences between the turbulent and transitional flow regimes (and their alteration) in our mesocosms was not sufficient to create enough shear stress or power to remove fine sediment or substantially alter sediment dynamics. However, Boulton et al. (2004) showed that artificial floods, which created a three-fold increase in discharge, only caused limited change in sediment dynamics within bed sediment. Whilst it may be hard to draw any generalities from individual studies, as local hydraulic conditions will influence fine-grained sediment dynamics, Jones et al. (2015) demonstrated that the increased flow used in the mesocosms resulted in increased penetration of oxygen into the stream bed and affected the distribution of hyporheic invertebrates, with a significant interaction between the flow and sediment treatments. Yet flow had no apparent ameliorating effect on the benthic macroinvertebrate assemblage, indicating that the macroinvertebrates living at the surface of the stream bed were not affected by conditions deeper within the hyporheos and suggesting that any difference in assemblage was due to the physical effects of the added fine-grained sediment at the surface.

Flow had a significant effect on the trait assemblage. Furthermore, the alteration in flow after day 40 led to a shift in prevalent traits to a condition most closely resembling the corresponding unaltered flow treatments. After 70 days, larger sized, ovoviviparous and asexually reproducing macroinvertebrates tended to be more prevalent in slow flows, whereas intermediately-sized macroinvertebrates that laid isolated cemented eggs or clutches of cemented eggs tended to be associated with high flows. These results indicate that the macroinvertebrate community rapidly responded in a predictable way to the changes in flow. 

sediments was primarily driven by the differences in abundances of seven taxa. Higher densities of

314 four taxa, Caenidae, Dytiscidae, Hirudinea and Hydracarina, were found in clean sediment whereas three families, Baetidae, Ephemeridae and Leuctridae, were found at higher densities in the experimentally colmated sediment, suggesting that colmation can have both positive and negative impacts, depending on individual taxa. Correspondingly, we found a significant effect of fine-grained sediment addition on the benthic macroinvertebrate trait assemblage; with relatively small size (maxiumum size between $0.5-1 \mathrm{~cm}$ ) and animals with more than one life cycle per year associated with the experimental addition of fine-grained sediment. We set up our experimentally colmated sediments to mimic changes to bed composition resulting from increased inputs of fine-grained sediment from catchments, where the mean size of particles becomes smaller, interstices between larger particles become filled and a surface drape of deposited sediment occurs (Kaufmann et al.

324 2009). Most macroinvertebrate species have specific requirements of the substrate they occupy and tend to avoid patches that fail to meet their requirements (Peckarsky, 1991; Williams and Smith, 1996; Sarriquet et al. 2007). For example, blackfly larvae tether themselves by means of a posterior circlet of hooks onto strands of silk which they attach to comparatively clean substrate, and they avoid substrates covered by a surface drape of loose sediments (Bass, 1998). Several species of crawling mayfly larvae avoid finer, less stable substrates as they cannot grip them effectively (Ciborowski et al. 1977; Corkum et al. 1977). However, other species, for example, certain Chironomidae and

331 Ephemeridae, select finer sediments into which they build tunnels. Along with physical changes to 332 bed sediments, colmation can also impact the chemical environment, particularly to decrease oxygen

333 levels (Jones et al. 2012). Although we noted small changes to in $\mathrm{pH}$ and temperature in our 334 mesocosms, oxygen penetration in the bed was always greater than the sampling depth of $3 \mathrm{~cm}$ (Jones et al. 2015), suggesting that altered bed particle size structure was the main mechanism affecting macroinvertebrates. 
We used planned contrasts to test the hypothesis that low flows would have a lasting effect on invertebrate assemblages even after flows had been increased due to prior effects on the species present (Ledger et al. 2006; Ledger and Hildrew 2001). We identified legacy effects of prior flow conditions but contrary to our assumptions, found that prior high flows had a larger influence on assemblage structure after flow switching than prior low flows: the difference between the SS and FS treatments was larger than that between the FF and SF treatments. It appears that the invertebrate community established during prior high flows was more susceptible to the impact of reduced flow. Legacy effects were also apparent on trait composition, but here we found less of a differential effect of the flow switching treatments, leading to a conclusion that the trait assemblage was robust to changes in flow.

Differences in susceptibility to variation flow among invertebrate communities have been identified previously and attributed to differences in within-site heterogeneity (Dunbar et al. 2010). Here we highlight the importance of prior flows: both within-site heterogeneity and flow history will mold the habitat template that defines the community and its response to disturbance (Gjerløv et al. 2003). has been known for a long time (e.g. Ellis 1936). More recently, river managers have attempted to use the specific substrate requirements of taxa to develop indices to assess the impact of sediment run-off, such as the proportion of sediment-sensitive invertebrates (PSI: Extence et al. 2013). The PSI purports to provide a proxy to describe the extent to which the surface of river beds are composed of, or covered by, fine sediments. Yet, these indices have rarely been tested experimentally. Somewhat surprisingly, the taxa that responded to the experimental addition of fine-grained sediment appeared to contradict the PSI system. The taxa that were more abundant in the clean sediment (Caenidae, Dytiscidae and Hirudinea), have PSI scores that indicate they are tolerant of fine-grained sediment, whereas two of the taxa that were more abundant in the experimentally colmated sediment (Baetidae and Leuctridae) have PSI scores that indicate they are sensitive to sediment additions. Only Ephmeridae responded to the experimental addition of fine-grained sediment in the way predicted by 
the PSI system (Hydracarina are not scored). It is apparent that the PSI system does not accurately reflect the response of these macroinvertebrate taxa to additions of fine-grained sediment, and we suggest that diagnostic indices should be based on empirical data rather than expert opinion (e.g. Murphy et al. 2013).

The responses of the macroinvertebrates to the altered flows was consistent with Dewson et al. (2007), who indicated that overall macroinvertebrate abundance can increase or decrease in response to decreased flow, whereas macroinvertebrate richness commonly decreases because habitat diversity decreases. The differences in assemblage structure between the fast and slow flows were primarily driven by eight taxa, six of which were more abundant in the fast flows. The increased abundance of three of the six taxa (Baetidae, Ephemerellidae and Hydropsychidae) is consistent with Extence et al. (1999), who indicated these taxa are primarily associated with moderate to fast flows. In contrast, Extence et al. (1999) also included Leuctridae as typical of fast flows, but this family was more abundant in our slow flow mesocosms. In addition, although Hydroptilidae and Polycentropodidae were more abundant in our fast flow mesocosms, Extence et al. (1999) lists these taxa as primarily associated with slow flowing and standing waters. Only one taxon, Dytiscidae, was more abundant in the slow flow mesocosms and was listed by Extence et al. (1999) as associated with slow flowing waters. The contrasting results from the mesocosms and the classification of Extence et al. (1999) suggest that many taxa may have more flexible hydraulic requirements than previously thought.

\section{Conclusion}

Our study suggested that sediment accumulation associated with low flows (an increase in the proportion of bed fine sediment to $10 \%$ by weight) had detrimental ecological effects and the difference in flows in our mesocosms was not enough to ameliorate those effects. We found no interaction between our flow and sediment treatments. Our study also suggested that different faunas are associated with different flow rates or near-bed hydraulics. Taken together, these results suggest that to preserve or enhance ecosystems in regulated rivers, levels of minimal flows need to be 
maintained and that previous fast flow conditions can have lasting effects on the assemblage

392 characteristics of the community present during periods of low flow. However, further research is

393 required to evaluate if there are lower thresholds of fine sediment levels that result in ecological

394 impairment and to determine what flow thresholds are required to ameliorate colmation impacts. It

395 would also be an advantage to the management of regulated rivers to determine if the timing of high

396 flow conditions can be optimized to promote any long term, legacy effects.

\section{Acknowledgments}

398 The River Communities Group of Queen Mary, University of London is thanked for hosting Ivor 399 Growns during the summer of 2012. We thank the River Communities Group members, Amanda

400 Arnold, Chas Duerdoth, James Pretty, Adrianna Hawczak and John Blackburn for their enthusiasm 401 and macroinvertebrate identification skills. In addition we thank the staff of the Freshwater Biological 402 Association in East Stoke (John Davy-Bowker, Vanya Gordon, Stephanie Smith and Peter Vallins) for 403 all their help. Rob Rolls and Andrew Brooks commented on earlier drafts of this manuscript and we 404 thank the two anonymous reviewers whose comments greatly improved the original manuscript. This 405 work was supported by the European Union $7^{\text {th }}$ Framework Programme Theme ENV.2011.2.1.2-1 406 under Grant Agreement No. 282656 (REFORM - REstoring rivers FOR effective catchment 407 Management). 


\section{References}

Anderson, M.J. (2001) Permutation tests for univariate or multivariate analysis of variance and regression. Canadian Journal of Fisheries and Aquatic Sciences 58, 626-639.

Araujo, E.S., Marques, E.E., Freitas, I.S., Neuberger, A.L., Fernandes, R., and Pelicice, F.M. (2013) Changes in distance decay relationships after river regulation: similarity among fish assemblages in a large Amazonian river. Ecology of Freshwater Fish 22(4), 543-552.

Armitage, P.D. (1995) Faunal community change in response to flow manipulation. In Ecological basis for river management (Eds. D Harper and A Ferguson) pp. 59-78. (John Wiley \& Sons Ltd: Chichester)

Bass, J.A.B. (1998) 'Last-instar larvae and pupae of the Simuliidae of Britain and Ireland: a key with brief ecological notes.' (Freshwater Biological Association: Ambleside)

Biggs, B.J.F., Nikora, V.I., and Snelder, T.H. (2005) Linking scales of flow variability to lotic ecosystem structure and function. River Research and Applications 21(2-3), 283-298.

Boulton, A., Harvey, M., and Proctor, H. (2004) Of spates and species: responses by interstitial water mites to simulated spates in a subtropical Australian river. Experimental and Applied Acarology 34, 149-169.

Boulton, A.J., Scarsbrook, M.R., Quinn, J.M., and Burrell, G.P. (1997) Land-use effects on the hyporheic ecology of five small streams near Hamilton, New Zealand. New Zealand Journal of Marine and Freshwater Research 31, 609-622.

Brooks, A.J., Haeusler, T., Reinfelds, I., and Williams, S. (2005) Hydraulic microhabitats and the 
Brooks, A.J., Russell, M., Bevitt, R., and Dasey, M. (2011) Constraints on the recovery of invertebrate assemblages in a regulated snowmelt river during a tributary-sourced environmental flow regime. Marine and Freshwater Research 62(12), 1407-1420.

Brunke, M. (1999) Colmation and depth filtration within streambeds: Retention of particles in hyporheic interstices. International Review Of Hydrobiology 84, 99-117.

Bryce, S.A., Lomnicky, G.A., and Kaufmann, P.R. (2010) Protecting sediment-sensitive aquatic species in mountain streams through the application of biologically based streambed sediment criteria. Journal of the North American Benthological Society 29(2), 657-672.

Bunn, S.E., and Arthington, A.H. (2002) Basic Principles and Ecological Consequences of Altered Flow Regimes for Aquatic Biodiversity. Environmental Management 30(4), 492-507.

Carlisle, D.M., Wolock, D.M., and Meador, M.R. (2010) Alteration of streamflow magnitudes and potential ecological consequences: a multiregional assessment. Frontiers in Ecology and the

Chevene, F., Doleadec, S., and Chessel, D. (1994) A fuzzy coding approach for the analysis of long460 term ecological data. Freshwater Biology 31(3), 295-309.

Ciborowski, J.J.H., Pointing, P.J., and Corkum, L.D. (1977) The effect of current velocity and sediment on the drift of the mayfly Ephemerella subvaria Mcdunnough. Freshwater Biology 
Collins, A., and Anthony, S. (2008) Predicting sediment inputs to aquatic ecosystems across England and Wales under current environmental conditions. Applied Geography 28(4), 281-294.

468

Corkum, L.D., Pointing, P.J., and Ciborowski, J.J.H. (1977) The influence of current velocity and substrate on the distribution and drift of two species of mayflies (Ephemeroptera). Can. J. Zool.

472

Cortez, D.P., Growns, I.O., Mitrovic, S.M., and Lim, R.P. (2012) Effects of a gradient in river regulation on the longitudinal trends in water quality and benthic algal and macroinvertebrate assemblages in the Hunter River, Australia. Marine and Freshwater Research 63(6), 494-504.

Descloux, S., Datry, T., and Usseglio-Polatera, P. (2014) Trait-based structure of invertebrates along a

480

Ellis, M.M. (1936) Erosion Silt as a Factor in Aquatic Environments. Ecology 17(1), 29-42.

Dewson, Z.S., James, A.B.W., and Death, R.G. (2007) A review of the consequences of decreased flow for instream habitat and macroinvertebrates. Journal of the North American Benthological Society 26(3), 401-415.

Dunbar, M.J., Pedersen, M.L., Cadman, D., Extence, C., Waddingham, J., Chadd, R., and Larsen, S.E. (2010) River discharge and local-scale physical habitat influence macroinvertebrate LIFE scores. Freshwater Biology 55(1), 226-242. 
501

502

503

504

505

506

507

Extence, C.A., Chadd, R.P., England, J., Dunbar, M.J., Wood, P.J., and Taylor, E.D. (2013) The assessment of fine sediment accumulation in rivers using macroinvertebrate community response. River Research and Applications 29(1), 17-55.

Findlay, S., and Sinsabaugh, R.L. (1999) Unravelling the sources and bioavailability of dissolved organic matter in lotic aquatic ecosystems. Marine and Freshwater Research 50(8), 781-790.

Gibson, R.J. (2002) The effects of fluvial processes and habitat heterogeneity on distribution, growth and densities of juvenile Atlantic salmon (Salmo salar L.), with consequences on abundance of the adult fish. Ecology of Freshwater Fish 11(4), 207-222.

Gjerløv, C., Hildrew, A.G., and Iwan Jones, J. (2003) Mobility of stream invertebrates in relation to disturbance and refugia: a test of habitat templet theory. Journal of the North American Benthological Society 22(2), 207-223.

Growns, I., Chessman, B., Mitrovic, S., and Westhorpe, D. (2014) The effects of dams on longitudinal variation in river food webs. Journal of Freshwater Ecology 29(1), 69-83.

Harris, R.M.L. (2006) The Effect of Experimental Drought Disturbance on Macroinvertebrate Assemblages in Stream Mesocosms. University of Birmingham, Birmingham, U.K.

Hart, D.D., Biggs, B.J.F., Nikora, V.I., and Flinders, C.A. (2013) Flow effects on periphyton patches and their ecological consequences in a New Zealand river. Freshwater Biology 58(8), 15881602. 
Jones, I., Growns, I., Arnold, A., McCall, S., and Bowes, M. (2015) The effects of increased flow and fine sediment on hyporheic invertebrates and nutrients in stream mesocosms. Freshwater Biology 60(4), 813-826.

Jones, J.I., Murphy, J.F., Collins, A.L., Sear, D.A., Naden, P.S., and Armitage, P.D. (2012) The Impact of Fine Sediment on Macro-Invertebrates. River Research and Applications 28(8), 1055-1071.

Kaufmann, P.R., Larsen, D.P., and Faustini, J.M. (2009) Bed Stability and Sedimentation Associated With Human Disturbances in Pacific Northwest Streams1. JAWRA Journal of the American Water Resources Association 45(2), 434-459.

Kefford, B.J., Zalizniak, L., Dunlop, J.E., Nugegoda, D., and Choy, S.C. (2010) How are macroinvertebrates of slow flowing lotic systems directly affected by suspended and deposited sediments? Environmental pollution (Barking, Essex : 1987) 158(2), 543-550.

Kemp, P., Sear, D., Collins, A., Naden, P., and Jones, I. (2011) The impacts of fine sediment on riverine fish. Hydrological Processes 25(11), 1800-1821.

Lancaster, J., and Downes, B.J. (2010) Linking the hydraulic world of individual organisms to ecological processes: Putting ecology into ecohydraulics. River Research and Applications 26(4), 385-403.

Larned, S.T., Arscott, D.B., Schmidt, J., and Diettrich, J.C. (2010) A Framework for Analyzing Longitudinal and Temporal Variation in River Flow and Developing Flow-Ecology Relationships1. Journal of the American Water Resources Association 46(3), 541-553.

\footnotetext{
Ledger, M.E., Harris, R.M., Milner, A.M., and Armitage, P.D. (2006) Disturbance, biological legacies
} 
Ledger, M.E., Harris, R.M.L., Armitage, P.D., and Milner, A.M. (2008) Realism of model ecosystems: an evaluation of physicochemistry and macroinvertebrate assemblages in artificial streams. Hydrobiologia 617(1), 91-99.

553

Ledger, M.E., and Hildrew, A.G. (2001) Recolonization by the benthos of an acid stream following a drought. Archiv für Hydrobiologie 152(1), 1-17.

556

Marsh, T., and Hannaford, J. (2008) UK hydrometric register. Hydrological data UK series. Centre for Ecology and Hydrology, Wallingford, UK, 1-210.

559

Matthaei, C.D., Piggott, J.J., and Townsend, C.R. (2010) Multiple stressors in agricultural streams: interactions among sediment addition, nutrient enrichment and water abstraction. Journal of

Menéndez, M., Descals, E., Riera, T., and Moya, O. (2012) Effect of small reservoirs on leaf litter decomposition in Mediterranean headwater streams. Hydrobiologia 691(1), 135-146.

566 Applied Ecology 47(3), 639-649.

570

Murphy, J.F., Davy-Bowker, J., McFarland, B., and Ormerod, S.J. (2013) A diagnostic biotic index for assessing acidity in sensitive streams in Britain. Ecological Indicators 24(0), 562-572.

Nilsson, C., Reidy, C.A., Dynesius, M., and Revenga, C. (2005) Fragmentation and Flow Regulation of the World's Large River Systems. Science 308(5720), 405-408. 
577 Office of National Statistics (2014) Annual mid-year population estimates, 2013. In: Statistical $578 \quad$ Bulletin. Office of National Statistics, Newport UK.

579

Olsen, D.A., Matthaei, C.D., and Townsend, C.R. (2010) Effects of a depositional flood event on the hyporheos of a New Zealand stream. Fundamental and Applied Limnology / Archiv für

583

Palmer, M.A., Filoso, S., and Fanelli, R.M. (2014) From ecosystems to ecosystem services: Stream restoration as ecological engineering. Ecological Engineering 65, 62-70.

586

Peckarsky, B.L. (1991) Habitat selection by stream-dwelling predatory stoneflies. Canadian Journal of Fisheries and Aquatic Sciences 48, 1069-1076.

Poff, N.L., and Zimmerman, J.K.H. (2010) Ecological responses to altered flow regimes: a literature 591 review to inform the science and management of environmental flows. Freshwater Biology

593 55(1), 194-205.

Ruiz-Gonzalez, C., Proia, L., Ferrera, I., Gasol, J.M., and Sabater, S. (2013) Effects of large river dam regulation on bacterioplankton community structure. Fems Microbiology Ecology 84(2), 316-

601

Sagnes, P., Merigoux, S., and Peru, N. (2008) Hydraulic habitat use with respect to body size of aquatic insect larvae: Case of six species from a French Mediterranean type stream. 
Sarriquet, P.E., Bordenave, P., and Marmonier, P. (2007) Effects of bottom sediment restoration on interstitial habitat characteristics and benthic macroinvertebrate assemblages in a headwater stream. River Research and Applications 23(8), 815-828.

609

Tachet, H., Bournaud, M., Richoux, P., and Usseglio-Polatera, P. (2000) 'Invertébrés d'eau douce : systématique, biologie, écologie.' (CNRS Editions: Paris)

612

Vadher, A.N., Stubbington, R., and Wood, P.J. (2015) Fine sediment reduces vertical migrations of Gammarus pulex (Crustacea: Amphipoda) in response to surface water loss. Hydrobiologia, 111.

616

Wagenhoff, A., Townsend, C.R., and Matthaei, C.D. (2012) Macroinvertebrate responses along broad 620

Williams, D., and Smith, M. (1996) Colonization dynamics of river benthos in response to local changes in bed characteristics. Freshwater Biology 36(2), 237-248.

Ward, J.V., and Stanford, J.A. (1979) Ecological factors controlling stream zoobenthos with emphasis on thermal modification of regulated streams. In The ecology of regulated streams. (Eds. JV Ward and JA Stanford) pp. 35-55. (Plenum Press: New York) 
Table 1. Effect of experimental treatments on physico-chemical variables and macroinvertebrate richness, density, community and trait assemblage structure.

Pseudo- $F$ values and probability levels given for each source of variance in PERMANOVA models. The percent variance explained by each significant term is given in parentheses after the significance level. Degrees of freedom for biotic variables are given in parentheses.

\begin{tabular}{|c|c|c|c|c|c|c|c|c|}
\hline Source of variation & $\begin{array}{l}\text { Degrees of } \\
\text { freedom }\end{array}$ & $\begin{array}{l}\text { Electrical } \\
\text { conductivity }\end{array}$ & $\mathrm{pH}$ & Temperature & Richness & Density & $\begin{array}{l}\text { Community } \\
\text { assemblage } \\
\text { structure }\end{array}$ & $\begin{array}{l}\text { Trait } \\
\text { assemblage } \\
\text { structure }\end{array}$ \\
\hline Sediment type (ST) & $1(1)$ & $\mathrm{ns}$ & $48^{* * *}(5 \%)$ & $\mathrm{ns}$ & $14.6^{* * *}(14 \%)$ & $19.7^{* * *}(29 \%)$ & $3.5^{* * *}(4 \%)$ & $4.7^{* * *}(4 \%)$ \\
\hline Sampling occasion (SO) & $13(1)$ & $1218^{* * *}(90 \%)$ & $54^{* * *}(46 \%)$ & $221^{* * *}(93 \%)$ & $15.0^{* * *}(12 \%)$ & ns & $33.3^{* * *}(35 \%)$ & $49.7^{* * *}(49 \%)$ \\
\hline Flow scenario $(\mathrm{FS})$ & $3(3)$ & ns & ns & ns & $6.8^{* * *}(12 \%)$ & ns & $4.7^{* * *}(11 \%)$ & $13.7^{* * *}(13.8 \%)$ \\
\hline ST x SO & $13(1)$ & ns & $18^{* * *}(29 \%)$ & ns & ns & ns & ns & ns \\
\hline ST $x$ FS & $3(3)$ & ns & ns & ns & ns & ns & ns & ns \\
\hline $\mathrm{SO} \times \mathrm{FS}$ & $39(3)$ & ns & ns & ns & $7.9^{* * *}(25 \%)$ & ns & $4.4^{* * *}(15 \%)$ & $3.8^{* * *}(11 \%)$ \\
\hline $\mathrm{SO} \times \mathrm{ST} \times \mathrm{FS}$ & $39(3)$ & ns & ns & ns & ns & ns & $\mathrm{ns}$ & ns \\
\hline Channel(FS x ST) & $16(16)$ & ns & ns & ns & ns & ns & ns & ns \\
\hline \multicolumn{9}{|l|}{ Planned contrasts } \\
\hline \multicolumn{9}{|l|}{ Time 1} \\
\hline$(\mathrm{FF}, \mathrm{FS})$ vs $(\mathrm{SS}, \mathrm{SF})$ & 1 & & & & $31.7^{* * *}$ & & $18.0^{* * *}$ & $13.1^{* * *}$ \\
\hline$(\mathrm{SS}) \mathrm{v}(\mathrm{SF})$ & 1 & & & & ns & & ns & ns \\
\hline$(\mathrm{FF}) \mathrm{v}(\mathrm{FS})$ & 1 & & & & ns & & ns & ns \\
\hline \multicolumn{9}{|l|}{ Time 2} \\
\hline$(\mathrm{FF}, \mathrm{SF})$ vs $(\mathrm{SS}, \mathrm{FS})$ & 1 & & & & $9.1^{* *}$ & & $11.1^{* * *}$ & $9.4^{* * *}$ \\
\hline$(\mathrm{SS}) \mathrm{v}(\mathrm{FS})$ & 1 & & & & ns & & $2.9^{*}$ & $3.3^{*}$ \\
\hline$(\mathrm{FF}) \mathrm{v}(\mathrm{SF})$ & 1 & & & & ns & & $1.9^{*}$ & $4.5^{*}$ \\
\hline
\end{tabular}

ns - not significant, $* * *-p<0.001, * *-p<0.01, *-p<0.05$, FF - Fast/fast flow scenario, FS - Fast/slow, SS - Slow/slow, SF - Slow/fact. 
Table 2 Macroinvertebrate biological traits used with their associated trait classes.

\begin{tabular}{|c|c|c|}
\hline Trait & Trait-Class & Abbreviation \\
\hline Maximal potential size & $\begin{array}{l}\leq .25 \mathrm{~cm} \\
>.25-.5 \mathrm{~cm} \\
>.5-1 \mathrm{~cm} \\
>1-2 \mathrm{~cm} \\
>2-4 \mathrm{~cm} \\
>4-8 \mathrm{~cm} \\
>8 \mathrm{~cm}\end{array}$ & $\begin{array}{l}\text { MaxS_25cm } \\
\operatorname{MaxS} 55 \mathrm{~cm} \\
\operatorname{MaxS} \_1 \mathrm{~cm} \\
\operatorname{MaxS} 22 \mathrm{~cm} \\
\operatorname{MaxS} 4 \mathrm{~cm} \\
\operatorname{MaxS} 8 \mathrm{~cm} \\
\text { MaxSm8cm }\end{array}$ \\
\hline $\begin{array}{l}\text { Potential number of cycles per } \\
\text { year }\end{array}$ & $\begin{array}{l}<1 \\
1 \\
>1\end{array}$ & $\begin{array}{l}\text { Pcyc_lt1 } \\
\text { Pcyc_1 } \\
\text { Pcyc_gt1 }\end{array}$ \\
\hline Reproduction & $\begin{array}{l}\text { ovoviviparity } \\
\text { isolated eggs, free } \\
\text { isolated eggs, cemented } \\
\text { clutches, cemented or fixed } \\
\text { clutches, free } \\
\text { clutches, in vegetation } \\
\text { clutches, terrestrial } \\
\text { asexual reproduction } \\
\text { parthenogenesis }\end{array}$ & $\begin{array}{l}\text { Repr_ovo } \\
\text { Repr_ief } \\
\text { Repr_iec } \\
\text { Repr_ccf } \\
\text { Repr_cfr } \\
\text { Repr_cvg } \\
\text { Repr_ctr } \\
\text { Repr_asr } \\
\text { Repr_par }\end{array}$ \\
\hline Resistance forms & $\begin{array}{l}\text { eggs, statoblasts } \\
\text { cocoons } \\
\text { housings against desiccation } \\
\text { diapause or dormancy } \\
\text { none }\end{array}$ & $\begin{array}{l}\text { Rest_egg } \\
\text { Rest_coc } \\
\text { Rest_hou } \\
\text { Rest_dia } \\
\text { Rest_non }\end{array}$ \\
\hline Respiration & $\begin{array}{l}\text { tegument } \\
\text { gill } \\
\text { plastron } \\
\text { spiracle }\end{array}$ & $\begin{array}{l}\text { Resp_teg } \\
\text { Resp_gil } \\
\text { Resp_pla } \\
\text { Resp_spi }\end{array}$ \\
\hline Locomotion and substrate relation & $\begin{array}{l}\text { flier } \\
\text { surface swimmer } \\
\text { full water swimmer } \\
\text { crawler } \\
\text { burrower } \\
\text { interstitial } \\
\text { temporarily attached } \\
\text { permanently attached }\end{array}$ & $\begin{array}{l}\text { Loco_fli } \\
\text { Loco_ssw } \\
\text { Loco_swi } \\
\text { Loco_crw } \\
\text { Loco_bur } \\
\text { Loco_int } \\
\text { Loco_tpa } \\
\text { Loco_pat }\end{array}$ \\
\hline Food & $\begin{array}{l}\text { microorganisms } \\
\text { detritus }(<1 \mathrm{~mm}) \\
\text { dead plant }(>=1 \mathrm{~mm}) \\
\text { living microphytes } \\
\text { living macrophytes } \\
\text { dead animal }(>=1 \mathrm{~mm}) \\
\text { living microinvertebrates } \\
\text { living macroinvertebrates } \\
\text { vertebrates }\end{array}$ & $\begin{array}{l}\text { Food_mio } \\
\text { Food_det } \\
\text { Food_dep } \\
\text { Food_mip } \\
\text { Food_map } \\
\text { Food_dea } \\
\text { Food_mii } \\
\text { Food_mai } \\
\text { Food_vrt }\end{array}$ \\
\hline
\end{tabular}




\section{Supporting Information}

Table S1. Pseudo- $F$ values and probability levels for pairwise PERMANOVA comparisons of flow scenarios at Day 30 and Day 70.

\begin{tabular}{lll}
\hline Flow scenarios & Day 30 & Day 70 \\
\hline FF vs. SS & $2.5^{* *}$ & $2.4^{* *}$ \\
FF vs. FS & $\mathrm{ns}$ & $2.8^{* *}$ \\
FF vs. SF & $2.4^{* *}$ & $\mathrm{~ns}$ \\
SS vs. FS & $2.5^{* *}$ & $1.7^{* *}$ \\
SS vs. SF & $\mathrm{ns}$ & $1.9^{* *}$ \\
FS vs. SF & $2.5^{* *}$ & $2.9^{* *}$ \\
\hline FF - Fast/fast flow scenario, FS - Fast/slow, SS - Slow/slow, SF - Slow/fact.
\end{tabular}


Table S2. SIMPER results of macroinvertebrate taxa and trait-classes contributing to differences (Bray-Curtis distance) between flow scenarios. . Codes for trait-classes are explained in Table 2.

\begin{tabular}{|c|c|c|c|c|}
\hline Variable & $\begin{array}{l}\text { Mean density in fast } \\
\text { flows }\end{array}$ & $\begin{array}{l}\text { Mean density in slow } \\
\text { flows }\end{array}$ & $\begin{array}{l}\text { Dissimilarity } \\
\text { ratio }\end{array}$ & $\begin{array}{l}\text { Cumulative } \\
\text { percentage }\end{array}$ \\
\hline \multicolumn{5}{|l|}{$\underline{\text { Taxon }}$} \\
\hline \multicolumn{5}{|l|}{ Day 30} \\
\hline Athericidae & 0.64 & 0.03 & 3.12 & 4.85 \\
\hline Baetidae & 0.65 & 0.06 & 2.23 & 9.60 \\
\hline Dytiscidae & 0.14 & 0.62 & 1.63 & 13.69 \\
\hline Ephemerellidae & 0.69 & 0.20 & 3.36 & 17.54 \\
\hline \multicolumn{5}{|l|}{ Day 70} \\
\hline Hydropsychidae & 0.65 & 0.03 & 2.10 & 4.99 \\
\hline Baetidae & 0.56 & 0.10 & 2.08 & 8.75 \\
\hline Hydroptilidae & 0.45 & 0.00 & 1.09 & 12.45 \\
\hline Polycentropodidae & 0.47 & 0.04 & 1.29 & 15.94 \\
\hline Leuctridae & 0.52 & 0.61 & 1.24 & 19.38 \\
\hline$\underline{\text { Trait }}$ & $\begin{array}{l}\text { Mean prevalence in } \\
\text { fast flows }\end{array}$ & $\begin{array}{l}\text { Mean prevalence in } \\
\text { slow flows }\end{array}$ & & \\
\hline \multicolumn{5}{|l|}{ Day 30} \\
\hline MaxS_1cm & 0.40 & 0.34 & 1.04 & 8.39 \\
\hline Pcyc_gt1 & 0.51 & 0.56 & 0.99 & 15.61 \\
\hline Repr_cfr & 0.19 & 0.23 & 1.06 & 22.36 \\
\hline \multicolumn{5}{|l|}{ Day 70} \\
\hline Repr_ccf & 0.32 & 0.26 & 1.04 & 13.78 \\
\hline $\operatorname{MaxS} 1 \mathrm{~cm}$ & 0.36 & 0.29 & 1.32 & 24.99 \\
\hline
\end{tabular}


Table S3. SIMPER results of macroinvertebrate taxa and trait-classes contributing to differences (Bray-Curtis distance) between sediment types. Codes for trait-classes are explained in Table 2.

\begin{tabular}{|c|c|c|c|c|}
\hline Variable & $\begin{array}{l}\text { Mean density in clean } \\
\text { sediment }\end{array}$ & $\begin{array}{l}\text { Mean density in } \\
\text { experimentally } \\
\text { colmated sediment }\end{array}$ & $\begin{array}{l}\text { Dissimilarity } \\
\text { ratio }\end{array}$ & $\begin{array}{l}\text { Cumulative } \\
\text { percentage }\end{array}$ \\
\hline \multicolumn{5}{|l|}{ Taxon } \\
\hline Leuctridae & 0.37 & 0.49 & 1.27 & 3.1 \\
\hline Ephemeridae & 0.31 & 0.34 & 1.20 & 6.0 \\
\hline Dytiscidae & 0.36 & 0.24 & 1.14 & 8.9 \\
\hline Baetidae & 0.26 & 0.42 & 1.28 & 11.6 \\
\hline Hirudinea & 0.32 & 0.15 & 1.00 & 14.3 \\
\hline Hydracarina & 0.46 & 0.26 & 1.40 & 17.0 \\
\hline \multirow[t]{2}{*}{ Caenidae } & 0.33 & 0.27 & 1.20 & 19.6 \\
\hline & $\begin{array}{l}\text { Mean prevalence in } \\
\text { clean sediment }\end{array}$ & $\begin{array}{l}\text { Mean prevalence in } \\
\text { experimentally } \\
\text { colmated sediment }\end{array}$ & & \\
\hline \multicolumn{5}{|l|}{ Trait } \\
\hline Pcyc_gt1 & 0.483 & 0.502 & 0.84 & 11.05 \\
\hline Repr_ccf & 0.295 & 0.265 & 0.80 & 18.09 \\
\hline MaxS_1cm & 0.34 & 0.359 & 0.78 & 24.58 \\
\hline
\end{tabular}




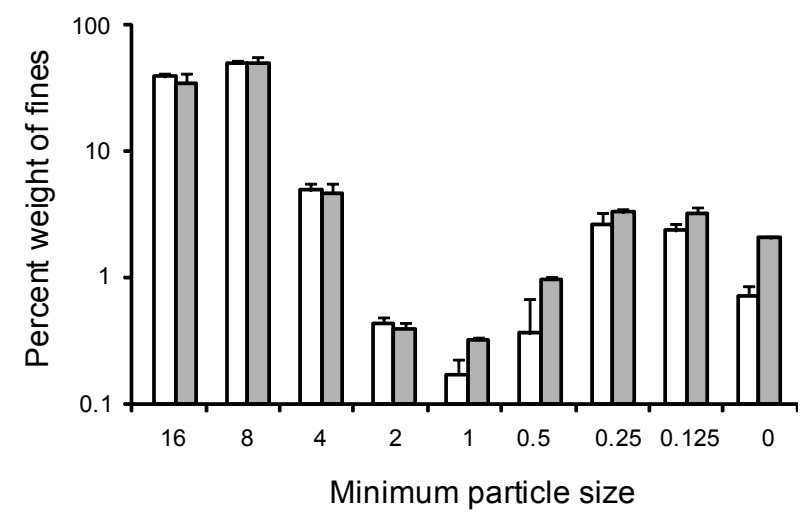

Figure 1. Mean percentage weight ( \pm 1 S.E.) of bed sediment particles among sizes classes for sediment loaded into mesocosms at Day 0. White columns indicate clean sediment and grey columns sediment with fine sediment added. 

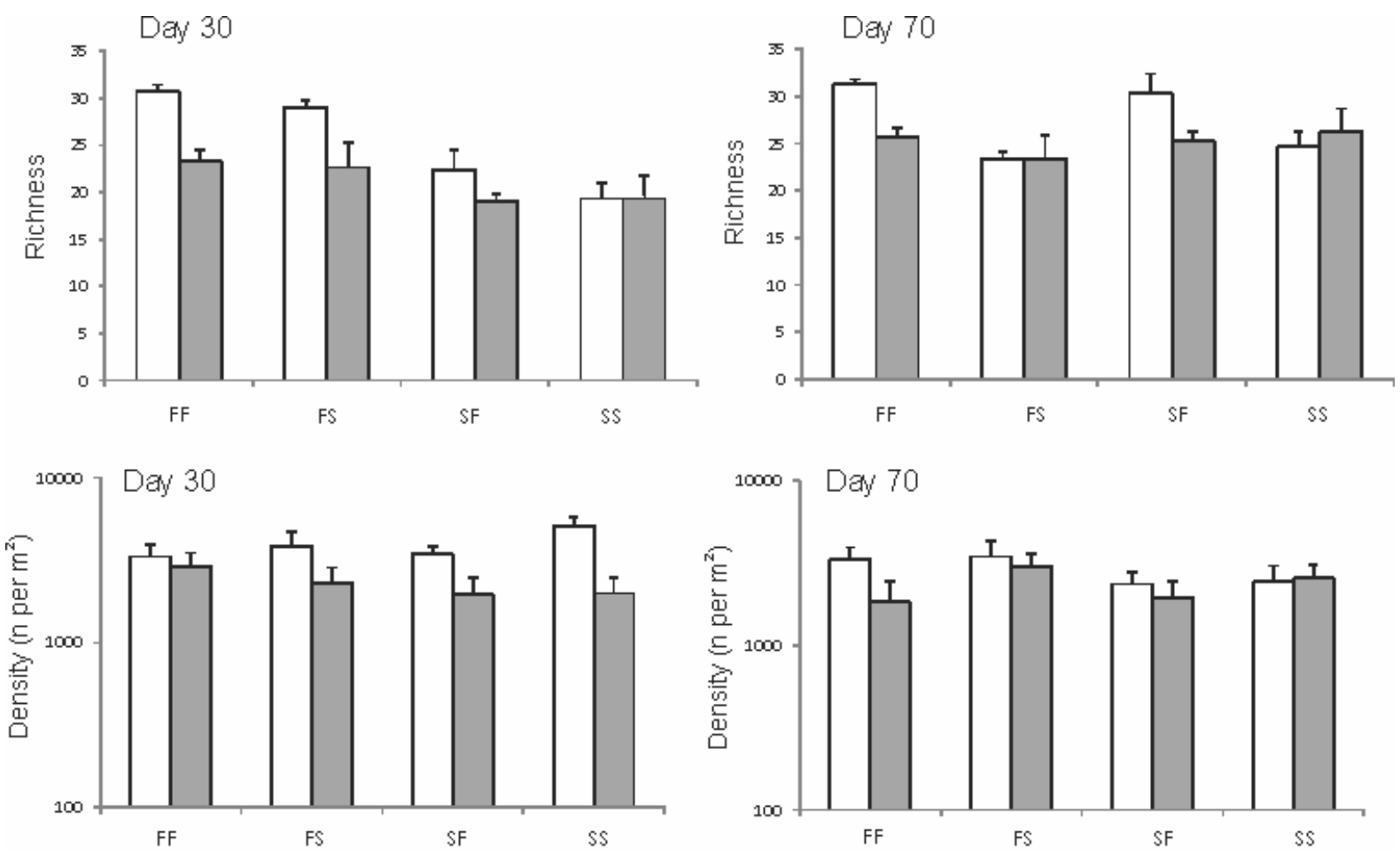

Flow scenario

Flow scenario

Figure 2. Mean macroinvertebrate richness and density ( \pm 1 S.E.) at Day 30 and 70 in four flow scenarios. White columns indicate clean sediment and grey columns experimentally colmated sediment. 

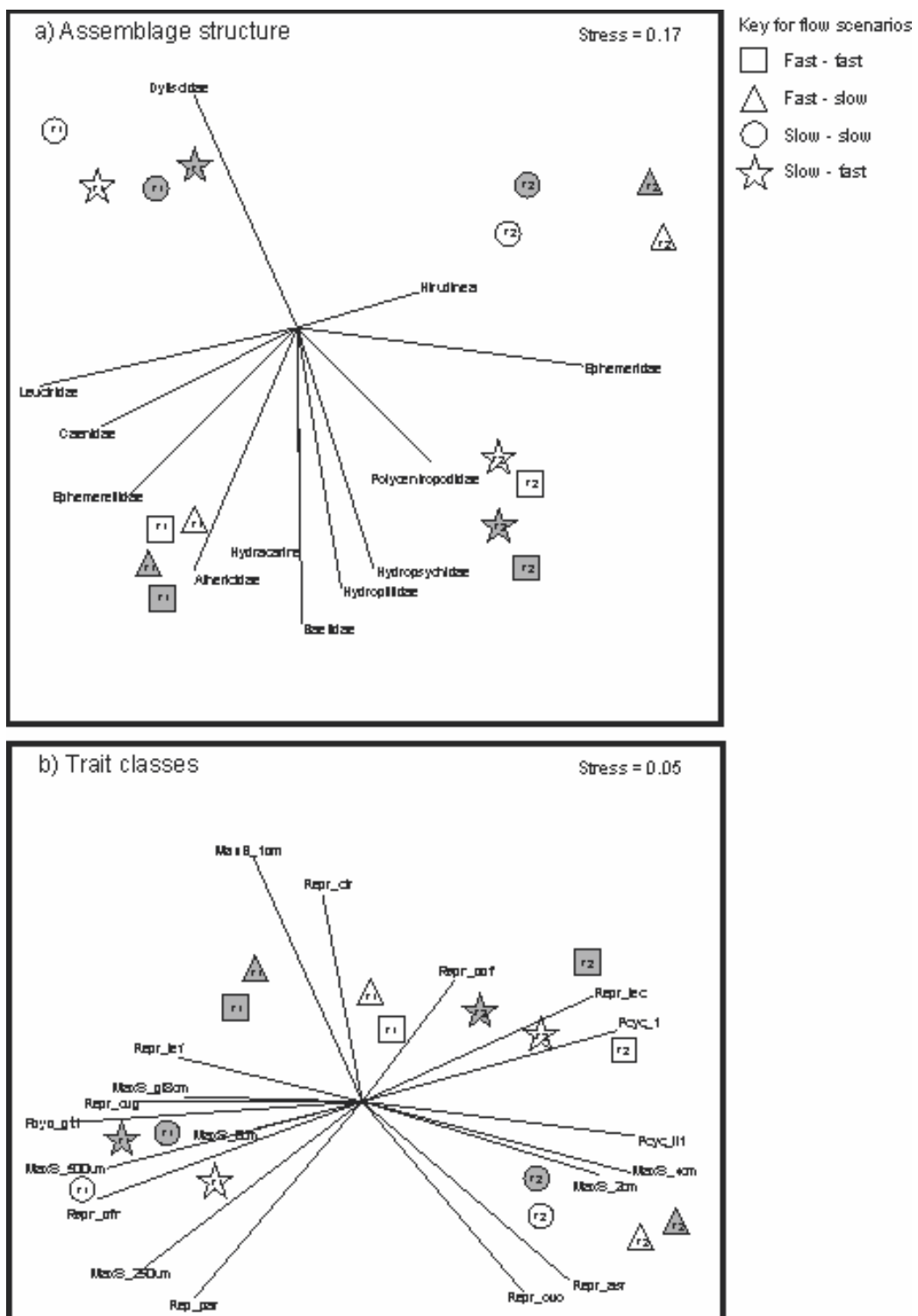

Figure 3. Ordination of centroids of (a) macroinvertebrate community assemblages and (b) trait assemblages from different flow scenarios at day 30 (T1) and day 70 (T2). White symbols indicate clean sediment and grey symbols experimentally colmated sediment. . Macroinvertebrate (a) taxa and (b) trait-classes that best discriminated between the different experimental treatments are included with the direction and relative length from the origin of each line indicating its association with each of the treatment centroids. 